\title{
OBSTRUCTIVE HYPERTROPHIC CARDIOMYOPATHY WITH CONCOMITANT MITRAL REGURGITATION TREATED WITH A SEPTAL MYECTOMY AND MV REPAIR: A CASE REPORT
}

Irena Mitevska ${ }^{1}$, Elizabeta Srbinovska ${ }^{1}$, Marijan Bosevski ${ }^{1}$, Sasko Jovev ${ }^{2}$, Omer Dzemali $^{3}$

${ }^{1}$ University Cardiology Clinic, Skopje, Macedonia

${ }^{2}$ Cardiac Surgery Clinic, Skopje, Macedonia

${ }^{3}$ Stadtspital Triemli Zürich, Switzerland

\author{
OPSTRUKTIVNA HIPERTROFIČNA KARDIOMIOPATIJA SA \\ PRIDRUŽENOM MITRALNOM REGURGITACIJOM KOJA JE LEČENA \\ PRIKAZ SLUČAJA \\ Irena Mitevska ${ }^{1}$, Elizabeta Srbinovska ${ }^{1}$, Marijan Bosevski ${ }^{1}$, Sasko Jovev $^{2}$, Omer Dzemali $^{3}$ \\ ${ }^{1}$ Univerzitetska kardiološka klinika, Skopje, Makedonija \\ ${ }^{2}$ Klinika za kardiohirurgiju, Skopje, Makedonija \\ ${ }^{3}$ Bolnica „Triemli“ Cirih, Švajcarska
} SEPTALNOM MIJEKTOMIJOM I REPARACIJOM MITRALNOG ZALISTKA:

Received / Primljen: 11. 08. 2017

Accepted / Prihvaćen: 28. 08. 2017.

\begin{abstract}
Case presentation

Hypertrophic cardiomyopathy (HCM) is the most common and very heterogeneous genetic cardiac disease with a different clinical presentation and prognosis. The overall prevalence of the disease is estimated between 0.05-0.2\% of the population. Left ventricular outflow obstruction at rest is present in about $20 \%$ of patients. Most of the patients have a normal life expectancy, however high risk patients might develop heart failure, atrial fibrillation, ventricular arrhyth-
\end{abstract} mias and sudden cardiac death.

We present the case of 47-year-old Caucasian man who was hospitalized at our clinic with a history of chest pain and shortness of breath on physical activity in the last six months, which caused significant limitations of his life quality. Hypertrophic obstructive cardiomyopathy was diagnosed in 2011, when the patient was put on therapy with beta blocker. Transthoracic echocardiography revealed normal systolic function, presence of systolic anterior mitral valve motion (SAM) with moderate mitral regurgitation (MR). There was a significant concentric left ventricular hypertrophy predominantly located in the ventricular septum. The intraventricular gradient at rest was 77.8 mmHg. MRI of the heart confirmed significant LV hypertrophy with regions of fibrosis at the septum. The patient shortness of breath worsened progressively in the last month (NYHA III) despite optimized medical treatment with maximal beta blocker dose. Surgical approach with septal myectomy was performed with mitral valve repair. There were no operative complications, with excellent postoperative recovery and complete symptoms resolution. Control Doppler echocardiograms revealed LVOT rest gradient reduction to $34 \mathrm{mmHg}$. The good operative results were still present 9 months after the intervention.

Our case confirmed that septal myectomy with $M V$ repair is an excellent treatment approach in young patient with obstructive hypertrophic cardiomyopathy and mitral valve involvement refractory to medical treatment.

Keywords: Hypertrophic cardiomyopathy, septal myectomy, mitral valve repair
SAŽETAK

Hipertrofična kardiomiopatija (HCM) je najčešce i vrlo heterogeno genetsko oboljenje srca sa kliničkom slikom koja može znatno da varira i razlicitom prognozom. Ukupna prevalenca ovog oboljenja se procenjuje na 0,05-0,2\% populacije. Opstrukcija izbacivanja krvi iz leve komore postoji u oko $20 \%$ pacijenata. Kod većine pacijenata se očekuje uobičajeno trajanje života, ali kod pacijenata sa visokim rizikom može da se razvije srčana slabost, fibrilacija pretkomora, aritmije komora i iznenadna srčana smrt.

Prikazan je slučaj belca starosti 47 godina koji je primljen u našu bolnicu zbog bola u grudima i osećaja gubitka daha tokom fizičke aktivnosti u poslednih 6 meseci, što je uzrokovalo znatno smanjenje kvaliteta života pacijenta. Hipertrofična, opstruktivna kardiomiopatija je dijagnostikovana 2011. godine, kada su pacijentu u terapiju uvedeni beta blokatori. Transtorakalnom ehokardiografijom je utvrđena fiziološka sistolna funkcija, postojanje antriornog kretanja mitralne valvule u sistoli sa umerenom mitralnom regurgitacijom. Postojala je znatna koncentrična hipertrofija leve komore pretežno u oblasti medukomorskog septuma. Intavenrikularni gradijent u mirovanju je iznosio 77,8 $\mathrm{mmHg}$. Pregledom magnetnom rezonacom potvrdena hipertrofija leve komore sa poljima fibroze u septumu. Osećaj gubitka daha kod pacijenta se značajno pogoršao (NYHA III) u poslednjih mesec dana uprkos primeni maksimalne doze beta blokatora. Izvršena je hirurška mijektomija septuma uz reparaciju mitralnog zalistka. Nije bilo komplikacija tokom operacije, postoperativni oporavak je bio izvrstan uz potpuni gubitak simptoma. Na kontolnim Doppler ehokardiogramima povrdeno je smanjenje gradijenta u izlaznom traktu leve komore na $34 \mathrm{mmHg}$. Dobri postoperativni rezultati su postojali $i 9$ meseci nakon operacije.

Ovaj slučaj potvrđuje da je mijektomija septuma uz reparaciju mitralnog zalistka odličan terapijski pristup u lečenju mladih pacijenata sa opstruktivnom hipertrofičnom kardiomiopatijom i insuficijencijom mitralnog zalistka kada postoji rafraktarnost na medikamentozno lečenje.

Ključne reči: Hipertrofična kardiomiopatija, septalna mijektomija, reparacija mitralnog zalistka. 


\section{INTRODUCTION}

Hypertrophic cardiomyopathy (HCM) is a very heterogeneous genetic cardiac disease with a different clinical presentation and prognosis. The overall prevalence of the disease is estimated between $0.05-0.2 \%$ of the population (1). The disease is characterized by asymmetric hypertrophy of the left ventricular (LV) and variable degrees of dynamic left ventricular outflow tract obstruction (LVOTO) due to the systolic anterior motion (SAM) of the anterior mitral leaflet. LV hypertrophy can be localized in the basal, mid or apical part of the septum. Left ventricular outflow obstruction at rest is present in about $20 \%$ of patients. Most patients achieve a normal life expectancy. On the other hand, in some patients, HCM is associated with disease complications which can result in disease deterioration or premature death.

There are three pathways of clinical progression: sudden cardiac death due to ventricular tachyarrhythmia, heart failure and atrial fibrillation associated with an increased risk of systemic thromboembolism and stroke. Treatment strategy is based on medical therapy, especially with the use of $\beta$ blockers and calcium-channel blockers , life style and physical activity modification $(1,2)$. Septal myectomy is the first treatment of choice in young patients who have LVOT obstruction at rest $>50 \mathrm{mmHg}$ and are symptomatic despite maximal medical therapy, with excellent results in experienced centers and properly selected patients (3).

In this report, we present a case of young symptomatic patient with marked hypertrophic obstructive cardiomyopathy with mitral valve regurgitation treated with septal myectomy and mitral valve repair.

\section{CASE REPORT}

A 47-year-old Caucasian man was hospitalized at University Cardiology Clinic in Skopje Clinical Center in October 2016 due to chest pain and severe dispnea. Patient reported the history of chest pain (Canadian Cardiovascular Society (CCS) class II) in the last year and shortness of breath on physical activity, which intensified in the last few days before the admission, which caused significant limitations of his life quality.

Hypertrophic obstructive cardiomyopathy was diagnosed in 2011, when the patient was put on therapy with beta blocker Bisoprolol $5 \mathrm{mg}$ daily. He had no history of coronary artery disease (CAD), and no risk factors for CAD, and no history of syncope or palpitations. There was no sudden cardiac death in the family members. Patient risk score for 5 year sudden cardiac death was 2.6, and there was no indication for preventive implantation of ICD.

His physical examination showed systolic murmur over aortic valve and lateral sternum. ECG showed left bundle branch block, with heart rate $65 \mathrm{bpm}$. His blood pressure was 120/70mmHg. All laboratory findings, lipids values and hs-
Troponin T were within normal limits. Pulmonary functions (pulmonary X-ray, spirometry and gas analyses) were normal.

Transthoracic echocardiography revealed normal systolic function with EF 76\%, left ventricular (LV) end diastolic dimension $53 \mathrm{~mm}$, LV end systolic dimension 28 $\mathrm{mm}$. There was a presence of systolic anterior mitral valve motion (SAM) with moderate mitral regurgitation (MR) due to SAM and mild posterior valve prolaps (Carpentier II) with moderate left atrial enlargement (LA 43mm, LA volume $58 \mathrm{ml}$ ). He had diastolic dysfunction of pseudonormalization type (DT 216ms; E/A 1,1; E' 0,06m/s; E/E' $15,9)$ and severe reduction of global longitudinal LV function (LV global longitudinal strain was $-12 \%$ ). The right ventricle had normal size and function with TAPSE 22, FAC $38 \%$. There was significant concentric left ventricular hypertrophy with predominant location in the ventricular septum with septal thickness of $32 \mathrm{~mm}$. Dimension of the posterior wall was $17 \mathrm{~mm}$. The intraventricular gradient at rest was $77.8 \mathrm{mmHg}$, provocable gradient on Valsalva maneuver was $95 \mathrm{mmHg}$. MRI of the heart confirmed significant LV hypertrophy with regions of fibrosis at the septum. Coronary angiography revealed normal coronary arteries with venticulography showing significant asymmetric hypertrophy, located predominately at the septum.

The patient shortness of breath worsened progressively in the last month (NYHA III) despite receiving medical treatment with maximal tolerated beta blocker dose (Bisoprolol 7,5mg total daily dose). The case was discussed together with the cardiac surgery team and the indication for septal myectomy was established.

The operation was performed in December 2016. The procedure was fully described to the patient, and a written informed consent was obtained before the operation. Surgical transaortic approach under cardiopulmonary bypass was first performed. Preoperative transesophageal echocardiography (TEE) was performed for detailed evaluation of LVOT obstruction and mitral valve apparatus. Conventional septal myectomy was undertaken to relieve SAM and LVOT obstruction. Mitral valve repair - edge to edge procedure sec. Alfierie and mitral ring annuloplasty with implantation of mitral ring type CG future- Medtronic size 32 followed. The procedure was performed at our clinic by visiting professor, cardiac surgeon from Triemli City Hospital in Zurich. There were no operative complications, with excellent postoperative recovery and complete symptoms resolution.

Patient was discharged in good condition and no symptoms after 8 days. Control Doppler echocardiogram before the discharge revealed LVOT rest gradient reduction to $34 \mathrm{mmHg}$. The good operative results were still present 9 months after the intervention with no gradient increase. Patient therapy is beta blocker Bisoprolol $5 \mathrm{mg}$ daily. He is asymptomatic with normal physical activity assessed on the last clinical visit in august 2017. ECG and echocardiography screening was performed on the close family members and we have not found any signs of HCM presence. 


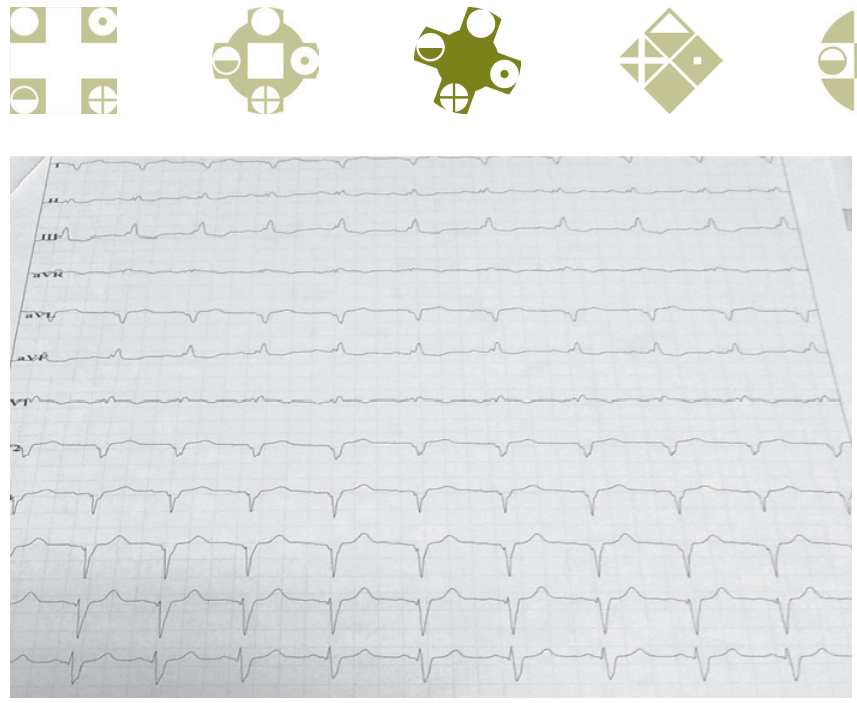

Figure 1.

Rest ECG showing left bundle branch block with heart rate 65bpm
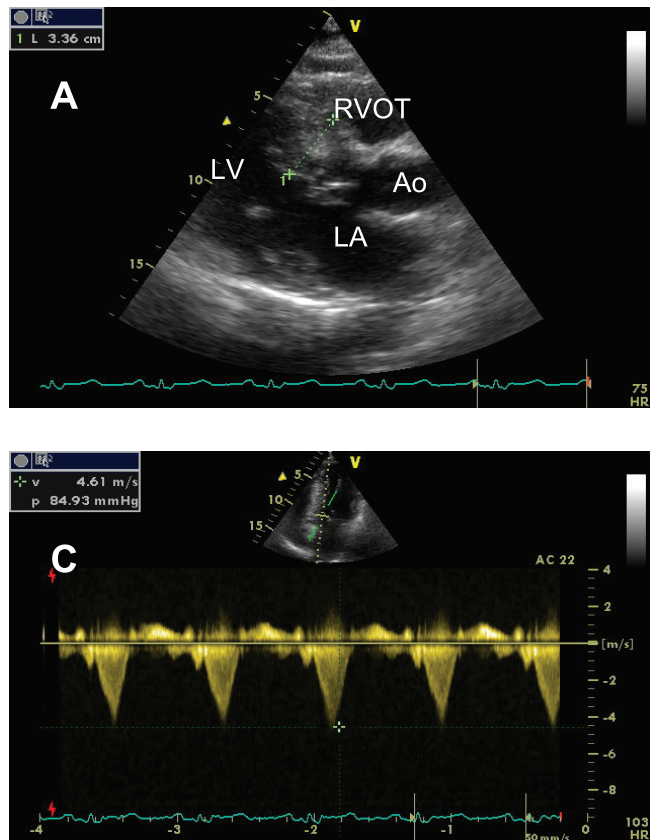

\section{DISCUSSION}

Septal myectomy has been established as a gold standard treatment for the relief of left ventricular outflow tract obstruction and cardiac symptoms in patients with obstructive hypertrophic cardiomyopathy with drug refractory functional limitations (4). The pharmacologic treatment of HCM is based on $\beta$ blockers, calcium-channel blockers and disopyramide. Although these medications improve symptoms, there is no evidence they influence prognosis in patients with LVOT obstruction. The biggest revolution in the HCM management is septal reduction therapy, despite the fact that this approach is used is the selected and relatively small number of symptomatic patients with LVOT obstruction at rest.
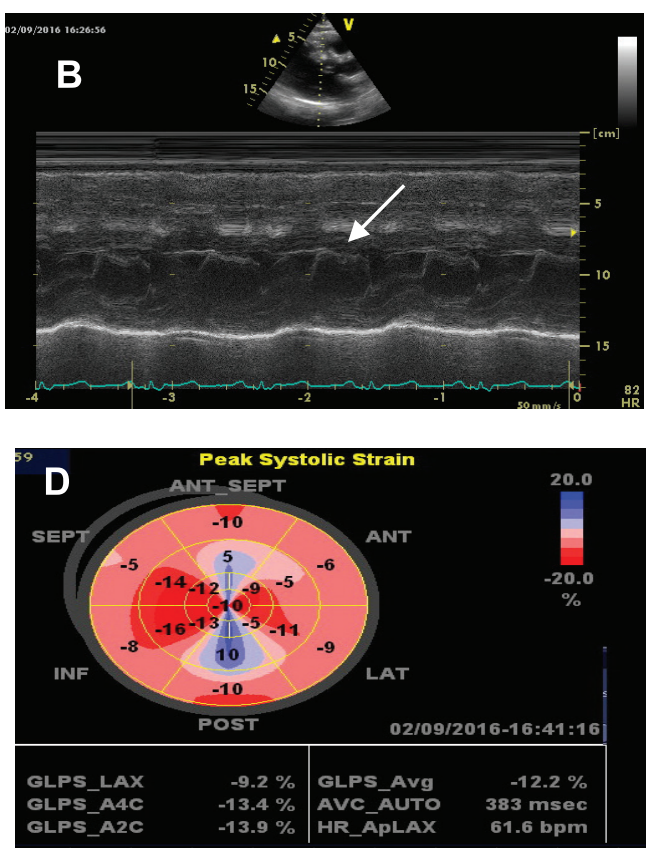

Figure 2. Two-dimensional echocardiograms. (A) Longitudinal, long axis view of the LV shows left ventricular hypertrophy confined to ventricular septum with regions of fibrosis. (B) M-mode of mitral valve showing the presence of systolic anterior mitral valve motion (SAM)- white arrow. (C) Presence of severe rest intraventricular gradient $84.93 \mathrm{mmHg}$. (D) Severely reduced global longitudinal left ventricular strain (-12\%) Ao, Aorta; LA, Left atrium; LV Left ventricle; RVOT, Right ventricle outflow tract.
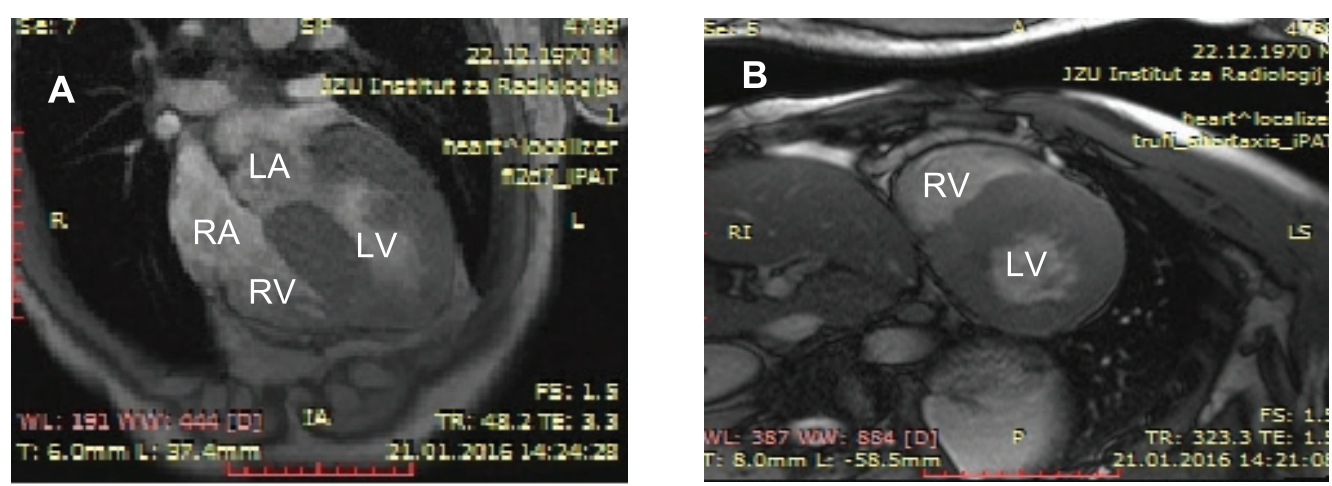

Figure 3

Nuclear magnetic resonance images of the patient. (A) Long-axis, four-chamber nuclear magnetic resonance (NMR) scan taken in end-systole shows hypertrophy confined to the left ventricular (LV) septum. (B) Short axis chamber view nuclear magnetic resonance (NMR) shows marked septal and lateral walls hypertrophy. LA, Left atrium; RA, Right atrium; RV, Right ventricle. 

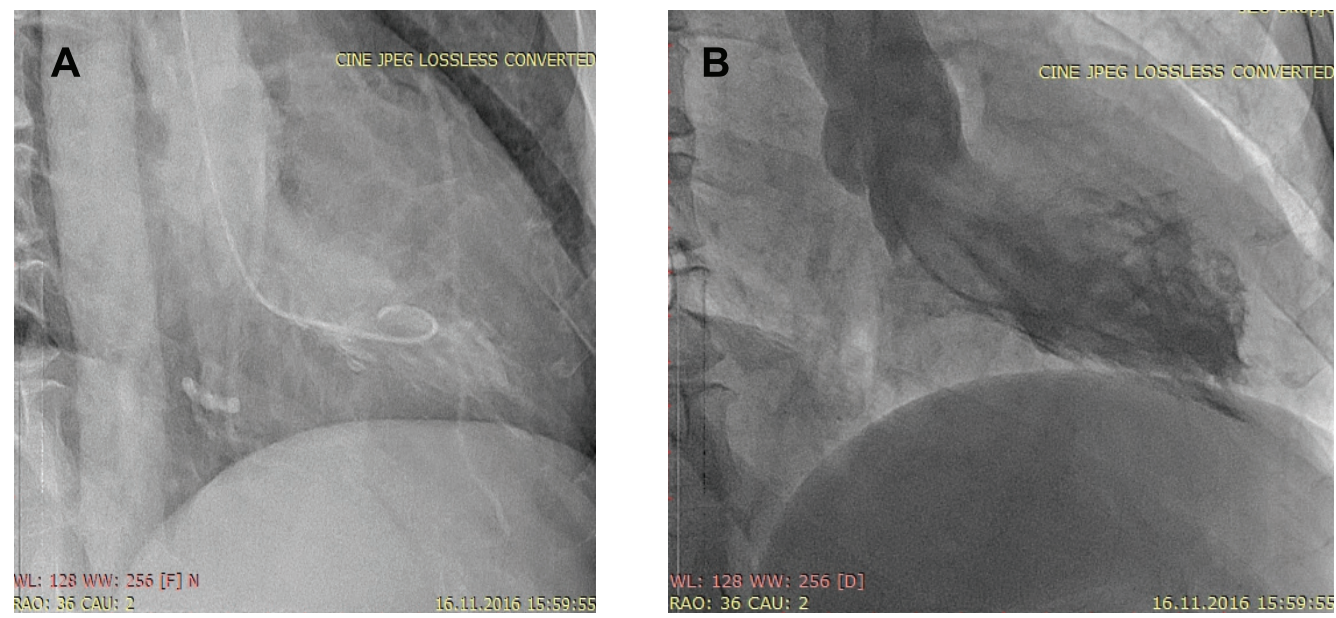

Figure 4

Cardiac catheterization ventriculograms. (A) Ventriculogram of the left ventricle shows severe left ventricular hypertrophy. (B) Ventriculogram of the left ventricle shows banana shaped left ventricle

Still, one of the most controversial issues in the treatment approach in patients with HCM concerns the use of percutaneous alcohol septal ablation (ASA) which causes a region of myocardial infarction aimed to reduce outflow tract obstruction (5). This procedure is dominating septal reduction treatment option in Europe. The scientific data suggests that although this procedure is associated with high success rate, high incidence of heart block and pacemaker implantation, arrhythmia risk, as well as less predictive and smaller final gradient reduction, position ASA as procedure with higher overall procedural complication rates compared to myectomy (6). On the basis of the latest scientific data, about $10-12 \%$ of the patients after ASA experience significant ventricular arrhythmias. Since myectomy does not produce intramyocardial scarring and fibrosis, there is no evidence that this procedure increases the risk of arrhythmias and left ventricular dysfunction. This method has advantages over septal alcohol ablation in younger patients with severe septal hypertrophy. One of the obvious advantages of myectomy is direct visualization of complex LV outflow tract anatomy with all structural abnormalities that lead to mechanical subaortic obstruction, mitral apparatus function and morphology. The concern that the mitral valve leaflets abnormalities can produce dynamic outflow obstruction, even after septal muscular resection, has led several surgeons to supplement myectomy with mitral valve repair in selected individuals (79). The aim of septal myectomy is to relieve SAM of the mitral valve as a cause of obstruction, not only to enlarge the LVOT anatomically. Frequently in some patients septal myectomy is modified with extended myectomy, partial excision of papillary muscles, mitral valve and subvalvular interventions when isolated septal myectomy is thought to be fully adequate. The choice of optimal procedure must be individualized based on age, comorbidities, degree of hypertrophy, suitability of coronary anatomy, primary mitral valve disease, patient preferences and operator experience. The standard septal myectomy (Marrow procedure) is not always an optimal procedure in every patient, especially with the mitral valve involvment. Structural and functional mitral valve and subvalvular abnormalities have been reported in patients with LVOT obstruction and HCM. The most frequent abnormalities are papillary muscle insertion directly into the anterior mitral leaflet, abnormal chordae tendineae attached to the ventricular septum or free wall and accessory papillary muscles, which may push the mitral leaflets toward the septum and produce LVOT obstruction. Most of the patients with concomitant abnormalities of the mitral valve and subvalvular apparatus can be managed without mitral valve replacement, and also other cardiac lesions can be repaired simultaneously. Additional operative procedures includes anterior mitral leaflet excision, "false chordae" excision and papillary muscle realignment.The most recent data from experienced centers are reporting low operative mortality for isolated septal myectomy (approximately 1\%). Septal myectomy also showed excellent late procedure results with over $90 \%$ of patients improving in NYHA class, which persisted in the follow-up period. Late survival in patients with obstructive hypertrophic cardiomyopathy treated with myectomy is similar to the same age healthy individuals (10-12). Additionally, it is reported the myectomy may be associated with decreased long-term risk of sudden cardiac death.

European and American guidelines on the management of HCM recommend that myectomy should be the preferred intervention for obstructive HCM in patients below 50 years (1). Over the past three decades, the technique for septal myectomy has evolved from the classic Morrow myectomy, to a more extensive left ventricular septal myectomy. Interventions are guided by intraoperative transesophageal echocardiography (TEE) with special attention to the septal anatomy and thickness, and mitral valve function (13). Data from the scientific literature shows long-term survival in patients with HCM after septal myectomy, is $99 \%, 98 \%$ and $95 \%$, at 1,5 and 10 years, accordingly. However, surgical myectomy does not reduce the need to assess 
each patient's risk for sudden cardiac death and to consider appropriate treatment modalities based on the SCD risk in individual patients (13). Mayo Clinic experience long term follow-up data shows that majority of patients will have an excellent symptomatic benefit and be able to have normal quality of life $(14,15)$.

HCM is a disease characterized by unexplained, marked and asymmetric left ventricular (LV) hypertrophy associated with non dilated ventricular chambers in the absence of another cardiac or systemic disease that are able to produce the magnitude of hypertrophy that fulfills the criteria for HCM (1). Clinically, HCM is usually recognized by a maximal LV wall thickness $>15 \mathrm{~mm}$. However, it should be underscored that in principle, any degree of wall thickness is compatible with the presence of the HCM genetic substrate. Echocardiography is the established method of choice for the diagnosis and prognosis of HCM, but also helps resolve several diagnostic challenges in HCM. The method enables differentiation of HCM from athlete's heart, left ventricular hypertrophy in hypertension and aortic stenosis, isolated basal septal hypertrophy in adults, apical forms of HCM, non-compaction cardiomyopathy and infiltrative myocardial disease. In order to establish the diagnosis of HCM, a systematic echocardiography approach is necessary. The echocardiography examination should include confirming of LV hypertrophy, assessment of LVOT obstruction, systolic anterior motion - SAM, mitral valve apparatus assessment, assessment of systolic and diastolic LV function and left atrial size. Strain imaging assesses subclinical LV dysfunction even in the presence of normal LVEF (15). The following two-dimensional (2D) echocardiography criteria are used to aid diagnosis: 1 . Unexplained maximal wall thickness $>15 \mathrm{~mm}$ in any myocardial segment, or 2. Septal/posterior wall thickness ratio $>1.3$ in normotensive patients, or 3 . Septal/posterior wall thickness ratio $>1.5$ in hypertensive patients (16).

It is clinically important to distinguish between the obstructive and nonobstructive forms of HCM because management strategies depend on the presence or absence of symptoms caused by obstruction. For HCM, it is the peak instantaneous LV outflow gradient rather than the mean gradient that influences treatment decisions. Up to one third of patients with HCM have rest LVOT obstruction (defined as gradients $\geq 30 \mathrm{~mm} \mathrm{Hg}$ ). Another one third have physiologically provoked gradients $(<30 \mathrm{~mm} \mathrm{Hg}$ at rest and $\geq 30 \mathrm{~mm} \mathrm{Hg}$ with physiologic provocation) $(16,17)$. The final one third have the nonobstructive form of HCM (gradients $<30 \mathrm{~mm} \mathrm{Hg}$ at rest and with provocation). Marked gradients $\geq 50 \mathrm{~mm} \mathrm{Hg}$, either at rest or with provocation, represent the conventional threshold for surgical or percutaneous intervention if symptoms cannot be controlled with medications $(16,17)$.

Magnetic resonance imaging is also important imaging modality in HCM. The extensity of myocardial fibrosis has prognostic implications.

We have presented a case of young symptomatic patient with obstructive HCM and moderate MR, who was successfully treated with septal myectomy and mitral valve repair. LVOT gradient fall to $25 \mathrm{mmHg}$. He has fast clinical improvement, LVOT gradient reduction and excellent quality of life during the 9 months follow up.

\section{CONCLUSION}

Our case confirmed that surgical myectomy in combination with mitral valve repair in obstructive HCM and moderate MR is safe and improves quality of life performed by experienced surgeon. In accordance with latest guidelines and consensus panel recommendations, the presented case support septal myectomy as the excellent treatment choice for $\mathrm{HCM}$ in young patients with severe drug-refractory symptoms caused by LV outflow obstruction.

\section{Conflict of interests:}

Not declared

\section{REFERENCES}

1. 2014 ESC Guidelines on diagnosis and management of hypertrophic cardiomyopathy: the Task Force for the Diagnosis and Management of Hypertrophic Cardiomyopathy of the European Society of Cardiology (ESC). Eur Heart J 2014; 35(39):2733-79.

2. Prevalence of hypertrophic cardiomyopathy in a general population of young adults. Echocardiographic analysis of 4111 subjects in the CARDIA Study. Coronary Artery Risk Development in (Young) Adults Maron BJ, Gardin JM, Flack JM, et al.. Circulation. Aug 15 1995;92(4):785-9.

3. Hypertrophic cardiomyopathy: current understanding and treatment objectives. Soor GS, Luk A, Ahn E, Abraham JR, Woo A, Ralph-Edwards A, et al. J Clin Pathol. Mar 2009;62(3):226-35.

4. Maron BJ. Controversies in cardiovascular medicine. Surgical myectomy remains the primary treatment option for severely symptomatic patients with obstructive hypertrophic cardiomyopathy. Circulation 2007;116:196-206.

5. Leonardi RA, Kransdorf EP, Simel DL, Wang A. Metaanalyses of septal reduction therapies for obstructive hypertrophic cardiomyopathy: comparative rates of overall mortality and sudden cardiac death after treatment. Circ Cardiovasc Interv 2010;3:97-104.

6. Merrill WH, Friesinger GC, Graham TP Jr, Byrd BF 3rd, Drinkwater DC Jr, Christian KG, Bender HW Jr. Longlasting improvement after septal myectomy for hypertrophic obstructive cardiomyopathy. Ann Thorac Surg 2000;69: 1732-1735.

7. McIntosh CL, Maron BJ, Cannon RO, Klues HG. Initial results of combined anterior mitral leaflet plication and ventricular septal myotomy-myectomy for relief of left ventricular outflow tract obstruction in patients with hypertrophic cardiomyopathy. Circulation 1992;86:II60-II67. 
8. Matsui Y, Shiiya N, Murashita T, Sasaki S, Yasuda K. Mitral valve repair and septal myectomy for hypertrophic obstructive cardiomyopathy. J Cardiovasc Surg 2000; 41:53-56.

9. Kofflard MJ, van Herwerden LA,Waldstein DJ, Ruygrok P, Boersma E, Taams MA, ten Cate FJ. Initial results of combined anterior mitral leaflet extension and myectomy in patients with obstructive hypertrophic cardiomyopathy. J Am Coll Cardiol 1996;28:197-202.

10. Maron BJ, McKenna WJ, Danielson GK, Kappenberger LJ, Kuhn HJ, Seidman CE, Shah PM, Spencer WH, Spirito P, ten Cate FJ, Wigle ED. American College of Cardiology/European Society of Cardiology Clinical Expert Consensus Document on Hypertrophic Cardiomyopathy: A report of the American College of Cardiology Foundation Task Force on Clinical Expert Consensus Documents and the European Society of Cardiology Committee for Practice Guidelines. J Am Coll Cardiol. 2003 Nov 5;42(9):1687-713.

11. Echocardiography in the treatment of hypertrophic cardiomyopathy Musat D, Sherrid MV. Anadolu Kardiyol Derg. Dec 2006;6 Suppl 2:18-26.

12. Woo A, Williams WG, Choi R, Wigle ED, Rozenblyum E, Fedwick K, Siu S,Ralph-Edwards A, Rakowski H. Clinical and echocardiographic determinants of long-term survival after surgical myectomy in obstructive hypertrophic cardiomyopathy. Circulation 2005;111:2033-2041.

13. Ommen SR, Maron BJ, Olivotto I, Maron MS, Cecchi F, Betocchi S, Gersh BJ, Ackerman MJ, McCully RB, Dea- rani JA, Schaff HV, Danielson GK, Tajik AJ, Nishimura RA. Long-term effects of surgical septal myectomy on survival in patients with obstructive hypertrophic cardiomyopathy. J Am Coll Cardiol 2005; 46:470-476.

14. Dearani JA, Ommen SR, Gersh BJ, Schaff HV, Danielson GK. Surgery insight: septal myectomy for obstructive hypertrophic cardiomyopathy - the Mayo Clinic experience. Nat Clin Pract Cardiovasc Med 2007;4:503-512.

15. Leonardi RA, Kransdorf EP, Simel DL, Wang A. Metaanalyses of septal reduction therapies for obstructive hypertrophic cardiomyopathy: comparative rates of overall mortality and sudden cardiac death after treatment. Circ Cardiovasc Interv 2010;3:97-104.

16. 2011 ACCF/AHA Guidelines for the Diagnosis and Treatment of Hypertrophic Cardiomyopathy: a report of the American College of Cardiology Foundation/ American Heart Association Task Force on Practice Guidelines. Developed in collaboration with the American Association for Thoracic Surgery, American Society of Echocardiography, American Society of Nuclear Cardiology, Heart Failure Society of America, Heart Rhythm Society, Society for Cardiovascular Angiography and Interventions, and Society of Thoracic Surgeons. Gersh BJ, Maron BJ, Bonow RO, et al. J Thorac Cardiovasc Surg. 2011 Dec;142(6):e153-203.

17. Echocardiography in hypertrophic cardiomyopathy: the role of conventional and emerging technologies. Afonso LC, Bernal J, Bax JJ, Abraham TP. JACC Cardiovasc Imaging. 2008 Nov;1(6):787-800. 